\title{
Colonial thinking, educational policy and social development: The Calliandra in bloom
}

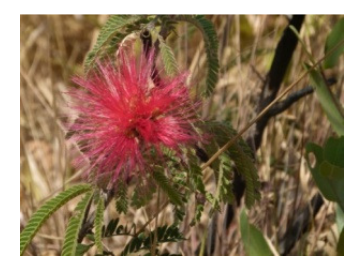

\author{
Martha Paiva Scárdua \\ marthap@ucb.br \\ Universidade Católica de Brasilia, Brazil \\ Afonso Galvão \\ acetaga@gmail.com \\ Universidade Católica de Brasilia, Brazil \\ Ranilce Mascarenhas Guimarães-Iosif \\ ranilceguimaraes@yahoo.com.br \\ Universidade Católica de Brasilia, Brazil
}

\begin{abstract}
This paper addresses problems of educational governance in globalization contexts, exploring actions that might become social development options, taking mainly into account Southern authors' formulations geared towards social development. We suggest, at the end, that such foundations may contribute for the construction of educational policies that will foster global citizenship in the context of the extremely competitive governance arena.
\end{abstract}

\section{Introduction}

A symbol of the Brazilian cerrado ${ }^{1}$, the Calliandra is a flower that represents the Brazilian version of the Phoenix myth: hope, resistance and strength cause it to bloom after a period of severe drought, when, amid the ashes, it bursts into red rays, bringing life to the arid landscape. Historically, the most significant mobilization moves of the Brazilian people followed pressures that reached the highest peak of unbearableness: moments of crisis usually trigger creative mechanisms to solve problems, giving shape to fertile ground for changes to occur.

Since colonial times until the 90's, Brazil has been the scenario of revolutions, political movements and uprisings staged by social strata that stood in the sidelines of our history for a long time. The annulment of the role played by uprisings and social movements in the construction of citizenship in Brazil and the transference of those feats to the middle or high parcels of society, or to those that were in power, characterized the tale of our history,

\footnotetext{
${ }^{1}$ Cerrado is a tropical savannah region typical of the plateaus of central Brazil, mainly located in the states of Goiás, Minas Gerais, and the Federal District.
} 
starting from the omission of social protagonism and the importance of popular power in the transformation of reality. (Gohn, 1995).

One of the most perverse effects of every colonization process, specifically of the Brazilian one, refers to the constitution of colonized minds from the logic of the mastercolonizer, something quite well developed by Hegel in his Phenomenology of the Spirit. Nearly two hundred years after independence, the Brazilian society and the Southern countries in general, still seem to be dependent on the projection of the Northern image. The South, as argued by Morin (2011), from the North's perspective, ends up constituting itself amid notions of backwardness and underdevelopment.

What effects has the denial of our authorship and of our conquests throughout history produced in us? What has prevailed in the Southern countries, submitted to the exclusive concepts coming from the North that, according to Morin (2011), has not recognized their qualities, virtues, art of living and ways of knowing?

The political crisis that resulted in the fall of the Berlin Wall in 1990, together with the review of values that had been happening much earlier than that, also brought about complex consequences to the Latin-American thinking. The period changes caused great commotion in the awareness, hopes and mental health of large sectors of the population. The convictions and utopias that had formed the basis for many people to shape their lives, identity and objectives tumbled down, fell apart, becoming anti-references (Virgil, 1997). Here, too, people stopped believing in progress - not the classical, Western one coming from the North - but in progress as a human capacity to change history, overcoming injustice and poverty. Latin-American society seems to be convinced that there is no way of overcoming reality in view of the failures of the "best" parties, of the punishments imposed to daring and rebelliousness, the stifled liberating experiences. The fall of the Berlin Wall tore down the convictions of an alternative society, held by many thinkers in Latin America. On the other hand, the illuminist ideal that culminates in the notion of a typical modernity order, the basis of the neoliberal thinking that ideologically structures the market economy, spectacularly tumbled down after the 2008 crisis.

In the past two decades, we lived a period of apparent social apathy in Brazil. The relation between the social, union movements and the government has stabilized, since the democratic, popular government rose to power, thus minimizing tensions, for the discourses of those institutions have become similar. However, there is a paradox: on the one hand, Brazil stands out for its economic growth, occupying the sixth place in the ranking of the most "developed" countries (World Bank, 2012), having exponentially increased a large part of the population's buying power. On the other hand, it is still marked with intense social inequality, placing third among the countries in the world with the largest gap between the poor and rich (Pnud, 2010). It behooves us to ask what kind of development is taking place: the consumption of the promises of modernity seems to have given place to a severe crisis of senses and insatiable desires, rather than the announced welfare. Santos (2007) explains that progressing in a consuming society frequently means going backward in the values scale. Only the conquest that enables understanding the experienced reality, seeking its structural remedies that will allow for the overcoming of one's limits is a definitive conquest.

The social injustice produced, perpetrated and kept by the instituted inequality, starting with a perverse globalization (Santos, 2010b), seems to be the basis for a sick society's set of symptoms that affect school in particular. Social spaces, like a school's, that gather a large number of children and young people, end up being true pressure cookers in which one is submitted to many kinds of violence. The drugs that circulate in those spaces produce symptoms like bullying, attention deficit, hyperactivity, depression, burn out 
syndrome, amid teachers and students, while they try to contain them. Moments of crisis have the positive characteristic of being spaces in which changes can be proposed and carried out that will involve, for example, the construction of educational policies geared towards social development.

It can be observed, however, that the action and ever greater influence of international organizations, like the International Labor Organization (ILO), the European Union (EU), the World Bank and the Organization for Economic Cooperation and Development (OECD), in educational policies involve actions that are more concerned with the economic order than with social development. Those institutions seem more interested in acting in favor of the individual's rights than the society's rights, protecting a mono-economy dominated by market force in the entire world, which also reverberates in education. The question we ask, therefore, is how should Brazil act in the arena of governance, taking advantage of the tensions produced by the cleansing movement and the transformation of Education in commodity?

This text endeavors to answer this set of questions, taking into account a composite view of several thinkers and researchers from the South, pointing out the need to constitute a model of alternative thinking, a new epistemology that will reorient Brazilian educational policies in the complex governance arena towards social development and justice.

\section{On the Phoenix flight over the south}

A recent documentary film (Dannoritzer, 2010) shows that a lamp that has been continually working since 1900 was discovered a few years ago in a small United States town. How can it be explained that, after 111 years, the lamps we currently produce have an active life of only 1000 hours? What can we say about so many other examples of obsolescence, cartel and externalization of costs that have guided economy, making the environmental sustainability and the dignity of workers throughout the world precarious? What makes the logic of profit and the exploitation of plusvalia be placed above people? What logic guides technology for a product to be considered precarious rather than to improve it? What can be said of the choices made for weaponry expenditures in detriment of investment in the eradication of the ill-fare (hunger, diseases, poverty) that troubles most of the world's population?

Once the constraints of Education, as well as those of the State, are acknowledged, in view of a "self-regulatory" capitalist economy, what should the university discuss and what must the governments and organized civil society oversee? What is the role of the scientific communities in the social and political issues? What ethics is to guide scientific work?

Steiner (2008) is in favor of a greater social and political orientation by the scientific communities. It is behooving to challenge the place taken by human sciences currently in Brazil, as we face near-collapse reality: how have such sciences considered the social problems and how have they affected them? Fourez (1995) points out the importance of the citizens's scientific and technological literacy in order that they can be more autonomous and participatory; likewise, he argues in favor of a common scientific transfer of information to the people that may empower them and provide them with knowledge that they can use, enabling them to act. In the field of Education, there is a great need of research translations for the teachers, managers and the society in general. According to Fusarelli (2008), decision-making based on research enables the school managers to produce more coherent and effective educational policies. If, on the one hand, high level scientific production can be observed - annually, only in the United States, over 20,000 articles are 
published in educational journals - on the other hand, those articles do not reach educational managers, very often on account of the language used, lack of time or expertise to understand the researches, but mainly, due to their questionable relevance for school needs.

This may be the moment to challenge how research in Education is carried out. What should be its essence? Shouldn't there be more research focused on problem solving and educational systems' needs (Fulsarelli, 2008)? The bases on which modern science has been supported deserve being re-examined. We are not advocating immediate utilitarianism of Science, as Comte (1996) foresaw, but its closeness and implication with life, its sharing with society, its orientation towards an ethics of care (Boff, 1999). Let us give orientation to the flight of the Phoenix towards the Calliandra in bloom. Let us go back in history, a little, to recover the origins of modernity.

\section{The emergence of the Southern thinking: Look at the "cerrado" calliandras.}

For Morin (2011), in order to achieve awareness of the qualities and virtues of the South, it is necessary to have a Southern Thinking that must be constructed starting from the experiences of the several "souths" without, however, excluding the North. Sodré (2012) says that:

There is no denying the importance of the institutional capital accumulated throughout Western history, whose synthesis can be perceived in achievements such as the state of right, representative democracy, free press, etc. But there is, likewise, no denying the signs of decline of this capital, which disavows any euro-cultural monism legitimized by an alleged universalism of reason. Particularly in the scope of Education, the practical consequences of this monist primacy upon the symbolic diversity of the various regions in the world are huge most of which are anchored to visual, sound and gesture forms of communication, not to written ones - especially with regard to the unequal recognition of the several means of appropriating and applying knowledges; hence, concerning to the ways of teaching and learning (p.22).

Several writers have contributed for the challenge of fighting against the abyssal lines that separate North and South with conceptual and political tools that will not reproduce them, as Sousa Santos (2010) highlights. Mignolo (2011) argues in favor of decolonizing knowledge and using decolonized knowledges as necessary measures to construct a fair and democratic society; Morin (2011) proposes the construction of a Southern thinking, capable of integrating and reconnecting knowledges, experiences and cultural perspectives reconnecting life itself; Santos (2010) proposes "another possible globalization", one that goes from the local to the global; Dussel (2010) argues in favor of a "retelling" of the tales of the peoples, which will replace the excluding historical narrative described by the "North"; Boff (2012) gives attention to the need to know how to take care of mother Earth and all its beings; Freire (2003) points out the power of liberation that starts from the awareness of one's own history and its possible and necessary transformation, reaffirming the existing dialectics between the oppressor and the oppressed; Suassuna (2012) calls attention to the acknowledgement and valuing of popular culture for the consolidation of a Brazilian national culture; Ribeiro (2006) narrates the construction of the Brazilian identity, starting from the wealthy conjunction of the peoples who arrived here, perceiving the constitution of a great Latin-American community. Santos (2004) invites us to break with the intellectual terrorism imposed by the one and only neoliberal thinking founded by orthodox economy. And, finally, Tarsila do Amaral (1928) and all who participated in the 1922 Modern Art Week stand out for having sought a Brazilian cultural-artistic identity. 
The challenge is how can we convey those basics and so many others into educational policies and new forms of governance that will take the place of the models that we have imported and emulated in Brazil? Initially, perhaps, it will be necessary to consider Sodré (2012) when he says that the decolonization of the educational process is necessary, liberating it or emancipating it from the Western monism that reduces all possibility of knowing, and from enunciating the truth to the cultural dynamics of a "pan-European" center. This movement, according to Sodré (2012), stimulates the "decolonization of criticism, i.e. the deconstruction of the intellectual belief that critical awareness is the literate's exclusive attribute or that it is up to the latter to critically illuminate the Other" (p. 19). With regard to that, Freire (2003) has already alerted us with his famous sentence : "no-one liberates anyone, no-one becomes free alone: man becomes free in communion" (p. 52). Once again, we resort to the principle of solidarity, essential for the consolidation of the Southern thinking that will give support to a new model of development and governance.

Olssen, Codd \& O'Neill (2004) called our attention to the urgency of a new world order in which nation-states may develop politics that will contribute for sustainable forms of governance. For those authors, educational policy is in the center of the global mission and is the key to global security, sustainability and survival in the XXIst century. Dale (2010) considers that "the national State is no longer the only actor in the realm of Education, neither necessarily the most important or evident" (p. 1.111). According to him, it is essential that we understand how educational governance works, as he understands it to be the combination and coordination of actions, actors/agents and scales by which Education is constructed and structured in national societies. It is important to even question up to what point Brazilian Education is still national.

Sharing the State's educational function with international organisms, the organized civil society, business enterprises, non-governmental organizations, among others, implies understanding that the educational policies are structured based on an exacerbated power struggle which causes us to question a nation's educational objectives. Dale (2010) considers pertinent to analyze, therefore, how and by whom educational policies are decided, governed, administrated and managed, and on what bases, and in whose interest they are determined and controlled. Hence, it is important to understand, as Galvão, Guimarães-Iosif, Scárdua \& Dassoler (2012) say:

[...] how the international organisms have influenced the educational policies in an attempt to strengthen the State's fighting mechanisms for a quality education for all Brazilians. It is urgent to make the governance arena more humane and that may occur from innovative, successful local experiences that may contribute to overcoming the historical vice of colonizing the thinking of the actors that dominate the field of global governance. The question we ask is about the participation of the civil society in the circle of the Brazilian educational governance. How has the State been represented in view of the pressures made by neoliberal international institutions? (p. 260)

Within this context, it is not possible to think of an Education for technical development detached from ethics; Education needs to develop global citizens that: i) manage to produce senses as they navigate in the "liquidity of modernity" (Bauman, 2011); ii) can understand and confront the power relations that perpetuate inequality and poverty in the world, being able to organize themselves collectively to strengthen civil society (GuimarãesIosif, 2009); iii) manage to give orientation and establish the foundations for the social and economic development of their nation on principles and human rights (Abdi \& Lynette, 2008); iv) and that they may point out ways of making another world real, one thought of in the light of social justice, sustainability, cooperation and democracy, making the social welfare State stronger. 
Pike (2008) considers that to question the assumptions of Education that support the dominant history, in order to promote the search for alternative versions, is a great challenge. Dower (2008) argues that the development of a global citizen requires the acknowledgement that all the problems experienced by human beings in the world matter, as well as the understanding of the need for co-responsibility with the others beyond our borders. Guimarães-Iosif (2009) defines some characteristics of emancipated global citizens: i) respect for cultural identity and diversity; ii) critical thinking; iii) indignation with regard to social injustice; iv) collective organization and participation in the fight against poverty, inequality or any situation of local or global oppression; v) awareness that one's actions affect everything and believe that they can do their part in constructing a better world; vi) question policies, agreements and national and international organizations that influence their way of understanding and living in a democratic and multicultural society. "[...] a citizen whose mind did not allow itself to be colonized by globalized neoliberal policies, but remained free to think on his or her own and to take an attitude in favor of social justice in the local, national and global communities!" (p. 177).

Afonso (2001) calls our attention to the fact that the decrease of State autonomy in educational policies is due to the installed crisis and to the need for a re-definition of roles in view of the globalization processes and the transnationalization of capitalism. This author observes that the social and educational policies have been tools of social control and State action legitimization, as well as of the dominant classes' interests, but they have also been strategies to make social, economic and cultural rights' realization and expansion, with repercussion on the improved living standards of social groups vulnerable to the capital logic.

Successive crises in the first world have shown that the development model proposed by the "north" is no longer sustainable for them either. After 60 years of development exportation and importation, what happened? By focusing on the results of the Structural Adjustment Programs submitted by western dominant institutions - like the World Bank and International Monetary Fund - in developing countries, Abdi (2012b) evaluates that, although those programs have produced some benefits, in general, they were detrimental to those countries' economic, political, cultural, technological as well as emotional welfare. But what is behind the failure of the development exportation model begun by U.S. President Truman in 1948? Abdi \&Guo (2008) explain that the problem with the development model from the "north" is its pretentious aspiration to solve all problems by importing development, which is contrary to the definition of the United Nations Development Program (Pnud), which is an alert on the care to be taken with regard to ensuring participation in the decisions on the processes of development. For Abdi \& Guo (2008),

Development should have been a feature of people's lives since the early formations of the first communities .... The discussion of social development is reduced to what is generally known as international development, which in many cases is limited to the exportations of ways and means of achieving better livelihood possibilities from the so-called developed parts of the world. The trouble with this euro-centric side of development is that it purports to solve everybody's problems, and starts with the problematic platform of pathologizing what may be termed, without any concrete categorizations, as lack of development or underdevelopment (p. 7).

Helen Clark, PNUD administrator and also chairman of the United Nations Development Group, considers that the XXIst century development must be based on the exchange of ideas, knowledge, innovation and sensible practice. She emphasizes the SouthSouth cooperation performance, which is in constant growth and which has been contributing for development in the whole world (Clark, 2012). Abdi (2012a) argues in favor of a strong relation between educational programs and social development. He considers that a country 
cannot construct without quality education, possible when based on equity and equality, those being the essential pillars to lever social development.

Rawls (1971) developed a theory of alternative justice Vs. the traditional concept of social contract that has dominated the North's philosophical tradition for so long, conceiving justice as equity. Likewise, Shultz (2012a) analyzes the concept of Global Social Justice as an important pillar to guide development, essentially focused on the social prism. With regard to social justice, Shultz (2007) still considers that:

The overarching theme of the social justice work being done to eradicate poverty and improve living standards of the marginalized part of the population is to strive for a better world. Not content to just challenge the existing unfair structures, people, throughout the world, are joining efforts to create social justice by way of deep compassion and accompaniment, by creating democratic spaces to build inclusive communities and by means of actions that connect the local experience with the shared global experience (p. 255).

Abdi \& Shultz (2008) also highlight the importance of respecting human rights as the key to reaching the necessary citizenship principles for the liberation of individuals and marginalized groups. Human rights may be understood as a global ethical liberation posture that challenges racist ethical emptiness and all other kinds of prejudice. If citizenship concerns access to rights, global citizenship can be understood as a universal extension of that citizenship. "Educating for a global citizenship means to help students, citizens and whole communities understand the global institutions and systems that interact with their daily lives" (Shultz, 2012b). Those precepts, hence, should serve as the basis for educational policies concerned with social development. For that matter, it is necessary to take care about the use of multiple concepts of global citizenship that have been utilized. Lynette (2007) categorizes three distinct approaches that focus on the global citizen. The neoliberal approach understands citizenship as the access to markets; the radical approach seeks to break with the structures that sustain global domination, and the transformational approach seeks to include and involve others on the basis of the sharing of their humanity.

The increase in the International Organizations' (IOs) activities, mainly those of Organization for Economic Co-operation and Development (OECD), starting from the 1990's, as well as the intensification of the mercantile aspect of Education, have produced significant changes in the field. The IOs now share educational governance with the Market and the State, transferred to an international politics arena, expanding its scope of action beyond national borders and forcing the introduction of regional or universally applicable models of Education. Education, as a public asset, traditionally the responsibility of the Nation-State, is increasingly more becoming a private, international good (Martens, Rusconi \& Leuze, 2007). Indeed, this trend follows the same line as that of the Structural Adjustment Programs established in developing countries, which have already proven a failure.

Nevertheless, the transformation of Education into a product implies the need to check its efficiency and effectiveness. An international gauging measure, the Program for International Student Assessment (PISA), created by the OECD, has been applied to assess the quality, equity and efficiency of the education systems. In their latest published report, Brazil occupied an unfortunate $53^{\text {rd }}$ place among the 65 countries assessed (OECD, 2010).

In accordance with the 2009 PISA results, the per capita GNP influences educational success, but this only accounts for $6 \%$ of the differences in the students' average performance, the other $94 \%$ reflect the potential of the public policies to make the difference. The most successful educational systems are usually those that have valued Education above all (OECD, 2010). The countries whose education systems acknowledge student diversity, their interests, and that value an individual approach to learning have had better performance. 
The Brazilian Federal Constitution of 1988 (Brazil, 1988), the product of the struggle of a variety of social movements, recognizes those differences but, in the social-institutional practices, the difficulty of respecting specific segments of our population is present. In the field of Education, when school failure is naturalized and the poor, black, native, peasant or learning-challenged student is held responsible, his social-historical context being disregarded, the idea of the Brazilian diversity is perpetuated as something negative (Duarte, Scárdua \& Caribé, 2010).

\section{New thinking, new practices: From the meeting of the Calliandra with the Phoenix}

Santos (2010b) argues for the construction of another form of globalization, based on an including, sustainable, solidary way of thinking that is already perceptible in local experiences that consider their culture and history. The darkness of Latin America in the 1990's, as described by Virgil (1997), gives way to a new time, guided no more by God, the State, or corporations, but by the people. Santos (2010b) considers that:

Another fact of our era that is indicative of the possibility of changes is the production of a population gathered together in increasingly smaller areas, which allows for a greater dynamism of the mixture of people and philosophies.... This shows that there is a true sociodiversity, historically much more significant than biodiversity itself. Add to those facts the advent of a popular culture that makes use of the technical means previously exclusive of the mass culture, it will enable them to affect the latter with an actual pay back or revenge (p. 21).

In the core of the so-called peripheral societies, experiences of social organization based on the ecology of the knowledges begin to emerge. The example of the African, Banto speakers and their Ubuntu philosophy can be highlighted, since it is based on the principles of sharing and mutual care (Ramose, 2010) and the Pachamama philosophy of the Andean native peoples, incorporated in the Equadorean legislation that foresees equal rights to Mother Earth and human beings (Equador, 2008). Our Brazilian Indians and their community way of living together in a sustainable way with the planet are also mentioned.

On a global level, the experience of the World Social Forum and of the World Education Forum, started in the late 1990's, consolidates a network of social participation that expands the mobilization and integration of the social movements in search of another possible world (Sousa Santos, 2005). Furthermore, virtual world networks of dispute have emerged, like the AVAAZ, which enable active participation of the world population in view of the non-compliance with human rights and environmental rules on the Planet. Those experiences are alternative examples of resistance to the excluding logic of neo-liberalism. What are the alternatives that have been proposed in the field of Education?

Concerned about their performance, schools, municipalities, states and the Federal Government have begun a series of actions to change the situation, some of which have carried out interesting possibilities, even if controversial, as was the case with the "Interactive School Development Plan", developed by the Ministry of Education - MEC (Brazil, 2012). The tool has been available on the internet for all Brazilian schools as of 2012 and enables participatory strategic planning, requiring systematic action of the school community for its success. The School Development Plan is one among several mechanisms whose objective is to increase education quality, combining speeches and practices either guided by marketing logic or by a humanistic perspective. It is part of the Education Development Plan (EDP), as a package created in 2007 that includes 40 programs aiming at, according to the words of the Minister of Education at the time, making real the quantitative goals established in the National Education Plan (NEP), considering stages, modalities and educational levels so as 
to construct a national Education system, seeking unity but also considering the implications between territorial organization, economic and social development and Education (Haddad, 2008).

On first sight, the EDP seems to be organically structured. However, when facts are contextualized, one can perceive, on the one hand, a quilt with scraps/actions that are customized around the BEDP and, on the other hand, that they are not articulated with the ENP's propositions. The reason why so many educational plans are created for Brazil is challenged: together with the NEP, the EDP for Brazil; together with the EDP, the All for Education Goals Commitment Plan, which foresees a collaboration regime between the Union and the municipalities, the Federal District and the States, and provides for the participation of the families and the community (Brazil, 2007), but which is constituted, nevertheless, on priority, by representatives and sponsors from large banks, foundations and corporations. We highlight the fact that the EDP is part of the World Bank's Structural Adjustment Plan, that bank being the main financer of educational reforms in the world.

Experience indicates that what is essential is not, perhaps, to create more laws, projects and programs. We need to urgently plan for a policy ecology, to paraphrase Sousa Santos, so as to intelligently integrate what there is, already, in order to ensure greater organic configuration to educational policies that do not distance themselves from the concept of education as a social process, and a process of integration and human development. This is the risk of having priority approaches on achievement, that increase the competition for higher performance, as is the case here in Brazil with regard to the race towards a higher Basic Education Development Rate (IDEB) at the schools. Many times, the evaluation makes no sense, since the results rarely go back to the students and teachers in the form of feedback.

But why is it that this occurs? What has been the objective of the evaluation policies adopted? Do they seek to improve public education or just show its failure? Up to what point do they contribute to social development? Afonso (2001) observes the strengthening of the evaluator-State that, as it focuses on external evaluation, disregarding the specificities of the educational processes contexts, it withdraws the autonomy of the Basic Education teaching systems. Those fragilities, among others, are the result of the influence of international educational policies seen without the necessary criticism by the actors that participate in educational governance, which shows the urgency of constructing global citizenship with the school community in order to overcome the new cycle of colonization just beginning, based on the creation of armored mechanisms and un-negotiable precepts for social development, to guarantee equity and equality.

In 2011, the Futura TV channel and the Industry Social Service (Sesi), both Brazilian, divulged the documentary Education Destiny (Sesi \& Futura, 2011b), which pictures education systems in the world that have stood out at PISA, be it for their success or their failure. Despite some constraints that bias the materials, mainly in the documentary made about Brazil, which favors the speech of interlocutors from non-governmental organizations, with a less critical line, in detriment of the official speeches that represent national Education more legitimately, important foundations in educational policies can be seen as belonging to a non-colonial thinking, even if mixed and mingled with neoliberal principles.

In China, the cooperation among schools that are performing well, with regard to teaching systems, stands out in contrast to those that are performing poorly - notwithstanding performance criteria, solidarity stands out as a political action. In Chile, an important lesson to be learned is respect for history, represented by the effort to implement State policies that are not interrupted by changes of government. Once more, we do not concern ourselves with the analysis of the implemented policies but with the respect for those policies' continuity 
process, which is a great Brazilian challenge. Still, there is the respect for differences and the offer of a quality equalitarian teaching system anywhere in Finland - also observed in Cuba (Carnoy, Gove, \& Marshall, 2009) - that even includes teacher training and development. In Canada, what stands out is the excellence of equity policies that decrease the impact of the students' social context in the outcomes they reach, starting from the respect of the teachers for the school community's cultural diversity.

It is behooving to highlight that the analysis of successful educational experiences and policies requires care not to go from an ignorance point (caos), understood as colonialism, to a point of knowledge (order), understood as solidarity, (Sousa Santos, 2010). Let us take the positive aspect of our ignorance and our knowledges - and all richness, beauty and mystery in them - and let us support each other with solidarity on humanity's accumulated ignorances and knowledges.

The movement of recovery and rebirth of a Southern epistemology, centered on the philosophy of liberation, places itself in favor of an ethical recuperation in the production process and applicability of scientific and technological knowledge. The time has come to overcome the barriers of fear and to daringly face the construction of a new, solidary, and scientific planetary reorientation, and to aggregate the Phoenix's and the Calliandra's philosophical knowledges and experiences. The way to follow to construct educational policies guided by this thinking under construction is everyone's and each one's responsibility, starting from his cultural locus. The importance of social protagonism in the creation of local alternatives of educational policies seems to be a good way. From the Brazilian State's point of view, this would mean a radical change of position, in the arena of international educational governance, in defense of respect for global social justice, human rights and the guarantee of Education as a social right. On the national level, the need for incentive and support to local initiatives is observed, as well as the stimulus to communicative interaction with the school communities, the offer of support tools to the organization, empowerment and strengthening of the social control mechanisms, and the provision of sufficient resources for its development. On the part of the school communities, it is imperative to constantly take care of the pedagogical practice and to have the courage to dare other forms of organization. The development of actions and programs that reach the school encouraging communication between the cultures makes it possible to break with a past that primed for cultural homogenization. The opening of schools to social participation, be it by means of participatory management, which includes the creation of School Councils, be it by the opening of the school environment for the community to develop their own demands, fosters communication and approximates distinct cultures, facilitating the understanding of the school over the challenges faced by the school community, making it possible to guide the school in its educational action, from the social transformation perspective.

Starting from that perspective, educational policies that aim at education quality should not be restricted to increasing learning of specific school contents but also deal with the development of citizenship and human rights. Social groups that have been marginalized for a long time should be recognized and, for that to happen, it does not suffice to place them in school but to first relocate them in communities, to include them, identify them, make them belong, and occupy them within that geographic, political, cultural and social space from which they were estranged every time that the school built walls that protected it from the violence it also produced.

We can conclude that acknowledging and overcoming the remains of excluding and inferior colonial thinking are essential measures for the reconstruction of educational 
practices in Brazil and in the world, and they can contribute for redesigning educational policies in the realm of educational governance and to foster justice and social development. May the Calliandra blossom and the Phoenix fly.

\section{References}

Abdi, A. (2012a). Lecture: Política educacional internacional, governança global e desenvolvimento social. Doutorado em Educação, Programa de Mestrado e Doutorado em Educação, Universidade Católica de Brasília, Brasília.

Abdi, A. (2012b) Políticas educacionais internacionais em tempos de globalização neoliberal: desafios ao desenvolvimento social. In Guimarães-Iosif, R. (Ed.). Política e governança educacional: contradições e desafios na promoção da cidadania (43-67). Brasília: Liber Livro \& Editora Universa.

Abdi, A. \& Guo, S. (2008). Education and social development: an introduction. In Abdi, A. \& Guo, S. (Eds) Education and Social Development: Global issues and analyses (pp.3-12). Rotterdam, the Netherlands: Sense Publishers.

Abdi, A \& Shultz, L. (2008). Continuities of racism and inclusive citizenship: framing global citizenship and human rights education. In Abdi, A. A. \& Guo, S. (Eds.). Education and Social Development: global Issues and Analyses. (pp.25-36). Rotterdam, the Netherlands: Sense Publishers.

Abdi, A \& Shultz, L. (2008). Educating for human rights and global citizenship: an introduction. In Abdi, A \& Shultz, L. (Eds.). Educating for human rights and global citizenship (1-23) Albany: State University of New York Press.

Afonso, A. J. (2001, agosto). Reforma do Estado e Políticas Educacionais: entre a crise do Estado-nação e a Emergência da Regulação Supranacional. Educação \& Sociedade. 22. (75). (pp. 15-32). Recuperado em 14 de outubro de 2012, de http://www.scielo.br/pdf/es/v22n75/22n75a03.pdf

Amaral, T. (1928). Abaporu. São Paulo.

Bauman, Z. (2011). Cartas do Mundo Líquido Moderno. Rio de Janeiro: Zahar.

Boff, L. (2012). Sustentabilidade e Educação. Recuperado em 12 de setembro de 2012, de http://leonardoboff.wordpress.com/2012/05/06/sustentabilidade-e-educacao/

Boff, L. (1999). Saber Cuidar - Ética do Humano: compaixão pela Terra. Petrópolis, Ed. Vozes.

Carnoy, M;. Gove, A. K \& Marshall, J. H. (2009). A vantagem acadêmica de Cuba: por que seus alunos vão melhor na escola. São Paulo: Ediouro.

Clark, H. (2012). Speech on the occasion of the Annual Ministerial Meeting of the Group of 77 and China. United Nations Headquarters, New York. Recuperado em 7 de outubro de 2012, http://www.undp.org/content/undp/en/home/presscenter/speeches/2012/09/28/helenclark-annual-ministerial-meeting-of-the-group-of-77-and-china/

Comte, A. (1996). Curso de Filosofia Positiva: Discurso preliminar sobre o conjunto do Positivismo: Catecismo Positivista. (Coleção Os Pensadores). São Paulo: Nova Cultural.

Dale, R. (2010, outubro/dezembro). A Sociologia da Educação e o Estado após a Globalização. Educação e Sociedadade. Campinas, SP. 31(113). pp. 1099-1120, Recuperado em 05 de outubro de 2010, de http://www.scielo.br/pdf/es/v31n113/03.pdf

Dannoritzer, C. (2010). The Light Bulb Conspiracy. (Documentário). 75 min. Espanha/França. Recuperado em 03 de outubro de 2012, de 
http://freedomlightbulb.blogspot.com.br/2012/05/lightbulb-conspiracy-documentaryby.html

Duarte, N. S., Scárdua, M. P. \& Caribé, R.L. (2010). O Pulo do Gato - jogos para alfabetizar. Brasília: Ideal.

Dussel, E. (2010). Meditações anticartesianas sobre a origem do antidiscurso filosófico da modernidade. In Sousa Santos, B. de \& Meneses, M.P. Epistemologias do Sul. (pp. 341-395) São Paulo: Cortez.

Dower, N. (2008). Are we all global citizens or are only some of us global citizens? The relevance of this question to education. In Abdi, A. A. \& Shultz, L. (Eds.) Educating for human rights and global citizenship. (pp.39-53) Albany, NY: State University of New York Press.

Equador (2008). Constitución Del Ecuador. Asamblea Constituyente. Recuperado em 30 de setembro de 2012 , de http://www.stf.jus.br/repositorio/cms/portalStfInternacional/newsletterPortalInternaci onalFoco/anexo/ConstituicaodoEquador.pdf

Fourez, G. (1995). Introdução à filosofia e à ética das ciências. São Paulo: Unesp.

Freire, P.(2003). Pedagogia do oprimido. (37a ed.) São Paulo: Paz e Terra.

Fusarelli, L. D. (2008). Flying (partially) blind: school leaders' use of research in decisionmaking. In Hess, F. M. (Ed.), When research matters: how scholarship influences education policy. (pp.) Cambridge, MA. Harvard Education Press.

Galvão, A., Guimarães-Iosif, R. M, Scárdua, M. P. \& Dassoler, O. B. (2012). Desafios da política e governança na promoção da cidadania no Brasil. In Guimarães-Iosif , R. M. (Ed.). Política e governança educacional: contradições e desafios na promoção da cidadania. (255-275) Brasília: Liber Livro e Universa.

Gohn, M. G. (1995). História dos movimentos e lutas sociais: a construção da cidadania dos brasileiros. São Paulo, SP.

Guimarães-Iosif, R. (2009). Educação, pobreza e desigualdade no Brasil: impedimentos para a cidadania global emancipada. Brasília: Liber Livro.

Haddad, F. (2008). O Plano de Desenvolvimento da Educação: razões, princípios e programas. Brasília: Ministério da Educação; Instituto de Estudos e Pesquisas Educacionais Anísio Teixeira.

Martens, K, Rusconi, A.\& Leuze, K. (2007). New arenas of education governance: the impact of international organizations and markets on education policy making. In Martens, K, Rusconi, A., \& Leuze, K. (Eds.) New arenas of education governance: the impact of international organizations and markets on education policy making. (pp. 3-15). New York: Palgrave.

Mignolo, W. D. (2003). Histórias locais, projetos globais: colonialidade, saberes subalternos e pensamento liminar. Belo Horizonte: UFMG.

Mignolo, W. D. (2011).The darker side of western modernity: Global futures, decolonial options. Usa: Duke University Press.

Ministério da Educação. Instituto Nacional de Pesquisas Educacionais. (2009). Projeto de Estudo sobre Ações Discriminatórias no âmbito Escolar, Organizadas de Acordo com Áreas Temáticas, a saber: étnico-racial, gênero, geracional, territorial, necessidades especiais, socioeconômica e orientação sexual. (Relatório Analítico Final). São Paulo: FIPE.

Ministério da Educação. Instituto Nacional de Pesquisas Educacionais. (2012). PDE interativo. Recuperado em 25 de setembro de 2012, de 
http://pdeescola.mec.gov.br/index.php?option=com_content $\&$ view=category $\& i d=37$ \&Itemid $=56$

OECD Organisation for Economic Co-operation and Development (2010). PISA 2009 Results: What Makes a School Successful? - Resources, Policies and Practices (Vol. 4). Recuperado em 15 de setembro de 2012, de http://dx.doi.org/10.1787/9789264091559-en

Olssen, M. Codd, J \& O’Neill, A. (2004). Reading educational policy in the global era. In Olssen, M. Codd, J \& O'Neill, A. Education policy: globalization, citizenship and democracy. (pp.1-17) Thousand Oaks, CA: Sage.

Pansarelli, D. (2012). A filosofia dusseliana da libertação e sua ética. Revista Urutágua, (4) Maringá: UEM, 2002. Recuperado em 21 de julho de 2012, de http://www.urutagua.uem.br//04fil_daniel.htm.

Pike, G. (2008). Reconstructing the legend: educating for global citizenship. In Abdi, A. A. \& Shultz, L. (Eds.). Educating for human rights and global citizenship. (223-237) Albany: State University of New York Press.

PNUD United Nations Development Programme (2010). Informe regional sobre desarrollo humano para América Latina y El Caribe 2010. Actuar sobre El futuro: romper la transmisión intergeneracional de la desigualdad. San Jose, Costa Rica. Recuperado em 1 de outubro de 2012, de http://hdr.undp.org/en/reports/regional/latinamericathecaribbean/RHDR-2010RBLAC.pdf.

Presidência da República. Casa Civil. Subchefia para assuntos jurídicos. Decreto $n^{\circ} 6.094$, de 24 de abril de 2007. Recuperado em 30 de setembro de 2012, de http://www.planalto.gov.br/ccivil_03/_ato2007-2010/2007/decreto/d6094.htm

Ramose, M.B. (2010). Globalização e Ubuntu. In Sousa Santos, B. de \& Meneses, M.P. (Eds). Epistemologias do Sul. (pp.175-220) São Paulo: Cortez.

Rawls, J. (1971). A theory of justice. EUA: Harvard College Press.

Ribeiro, D. (1995). O povo brasileiro: a formação e o sentido do Brasil. São Paulo: Companhia das Letras.

Santos, M. (2007). O espaço do cidadão. São Paulo: USP.

Santos, M. (2010a). O lugar e o cotidiano. In Sousa Santos, B. de \& Meneses, M.P. (Eds.) Epistemologias do Sul. (pp. 584-602) São Paulo: Cortez.

Santos, M. (2010b). Por uma outra globalização: do pensamento único à consciência universal. (19a ed.). Rio de Janeiro: Record.

Santos, T.dos (2004). Do terror à esperança: auge e declínio do neoliberalismo.Aparecida, SP: Ideias e Letras.

SESI \& FUTURA.(2011). Documentário Destino Educação. Recuperado em 11 de setembro de 2012, de http://www.youtube.com/watch?v=AZu9QFufWaw.

Shultz, L. (2007). Educating for global citizenship: Conflicting agendas and understandings. The Alberta Journal of Educational Research. 53(3) (pp.248-258).Fall

Shultz, L. (2012a). Lecture: Política educacional internacional, governança global e desenvolvimento social. Tese de Doutorado em Educação, Universidade Católica de Brasília.

Shultz, L. (2012b). Governança Global, neocolonialismo e respostas democráticas para políticas educacionais. In Guimarães-Iosif, R.M. (Ed.) Política e governança educacional: contradições e desafios na promoção da cidadania. (27-40) Brasília: Liber Livro e Editora Universa.

Sodré, M. (2012). Reinventando a educação: diversidade, descolonização e redes. Petrópolis, RJ: Vozes. 
Sousa Santos, B. de. (2005, outubro) A crítica da governação neoliberal: o Fórum Social Mundial como política e legalidade cosmopolita subalterna. Revista Crítica de Ciências Sociais, (72). p. 7 - 44.

Sousa Santos, B. de. (2010). Para além do pensamento abissal: das linhas globais a uma ecologia de saberes. In Sousa Santos, B. de \& Meneses, M. P. (Eds.) Epistemologias do Sul. (pp. 31-83) São Paulo: Cortez.

Steiner, G. (2008). A ciência está perto dos limites? In Steiner, G. (Ed.) A ciência terá limites? (pp. 13-32) Lisboa: Fundação Calouste Gulbenkian.

Teresi, D. (2008) Descobertas perdidas: as raízes antigas da ciência moderna, dos babilônios aos maias. São Paulo: Companhia das Letras.

Vilgil, J. M. (1997). Embora seja noite: a hora espiritual da América Latina nos anos 90. São Paulo: Paulinas.

WORLD BANK (2012). 2005 ICP Global Results: Summary table of results. Recuperado em 1 de outubro de 2012, de http://siteresources.worldbank.org/ICPINT/Resources/summary-tables.pdf. 